\title{
The CMA Code of Ethics and the donation of fresh embryos for stem cell research
}

\section{Jeffrey Nisker, Angela White}

T

The promises of human embryonic stem cell (hESC) research and the needs of Canadian scientists to acquire fresh human embryos with which to participate in this important field of inquiry may result in the unintended compromise of the professional obligations of Canadian physicians. ${ }^{1}$ The strong preference for fresh as opposed to cryopreserved embryos follows the work of South Korean scientists who have derived multiple stem lines using fresh human embryos, ${ }^{2,3}$ with an efficacy rate much higher than rates reported in studies involving cryopreserved embryos. Canadian scientist Andras Nagy confirmed recently that he indeed used fresh embryos provided by a Canadian physician for his successful stem cell derivation. ${ }^{4}$ However, since the advent of embryo cryopreservation in the late $1980 \mathrm{~s},{ }^{5}$ physicians have generally not offered their patients the choice to donate fresh embryos to research, since this choice could decrease their patients' chances of pregnancy or increase their risk of harm because of the additional cycles of menotropin drugs and oocyte retrieval surgery that may be required if the current treatment cycle does not result in a child). ${ }^{6}$ Canada's Assisted Human Reproduction (AHR) Act ${ }^{7}$ and the Canadian Institutes of Health Research (CIHR) Human Pluripotent Stem Cell Research Guidelines ${ }^{8}$ allow physicians to approach patients with the option of donating cryopreserved embryos no longer required for reproductive purposes. Although these documents prohibit the creation of embryos specifically for research purposes ${ }^{7,8}$ donation of fresh embryos created for reproductive purposes to research is not considered, nor is this possibility addressed in any Canadian professional practice guideline. A legislative and professional policy grey zone thus exists, which may lead to confusion about the professional obligations of physicians approaching their patients to donate fresh embryos.

In many countries, such as Great Britain ${ }^{9}$ and the United States (except in federally funded laboratories), ${ }^{10}$ the creation of human embryos specifically for research purposes is permitted; thus, a source of fresh embryos exists for stem cell scientists in those countries. In Canada, however, fresh embryos must come from patients engaged in in-vitro fertilization (IVF). The CMA Code of Ethics instructs physicians to "consider first the well-being of the patient" and "take all reasonable steps to prevent harm to patients" as fundamental responsibilities. ${ }^{1}$ These directions imply that physicians participating in IVF are obligated to maxi- mize their patients' chance of achieving pregnancy and minimize their patients' risk of harm. Because a woman's chance of pregnancy may be decreased by deciding against cryopreservation (for transfer in ensuing months) of all embryos not transferred to the woman in her treatment cycle, and because her risk of harm will be increased if additional IVF cycles are required for the same pregnancy rate per treatment cycle, the offer and acceptance of such a choice may be in conflict with the CMA Code of Ethics.

The CMA Code of Ethics also instructs physicians to "recommend only those diagnostic and therapeutic services that you consider to be beneficial to your patient or to oth-

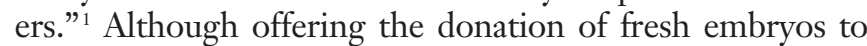
hESC research is not beneficial to the patient (indeed, it may be harmful), the donation may be beneficial to others, such as Canadians who have conditions that could be improved in the future by results from hESC research. Thus, a physician denying a patient the opportunity to donate fresh embryos to hESC research may be in conflict with the obligation to provide information that would enable the woman to make a free and informed decision in this regard.

However, a moral distinction may exist between the donation of fresh embryos for the potential benefit of others and the donation of other tissues, such as bone marrow. A woman undergoing IVF who is approached to consider donation of her embryos is already in a physician-patient relationship, with an inherent power differential, ${ }^{11,12}$ whereas donors of bone marrow and other tissues have not yet entered into such a relationship. Moreover, although the procedures involved are invasive and therefore potentially harmful to the donor, potential donors of bone marrow and other tissue are not in a position where their altruism might thwart a personal medical goal.

Because IVF patients generally trust their physicians never to present them with options that may decrease their chance of having a child or increase their risk of harm, these women may not understand and appreciate that there is a decrease in their likelihood of pregnancy and an increase in their risk of harm from donating a few fresh embryos. They also may feel compelled to comply with what they believe their physician wants them to do, to avoid offending the professional on whom they depend to help them deliver a child. ${ }^{12}$ The media "hype" associated with human embryonic stem cell research ${ }^{13}$ might further influence women to help their physician help others. 
A woman who, for religious or other moral reasons, chooses not to have her embryos cryopreserved, may be in the position to provide fresh embryos to stem cell research without decreasing her chance of pregnancy or increasing her risk of harm. However, such value systems are likely to prevent the woman from donating embryos to research. Someone who has chosen preimplantation genetic diagnosis $^{14}$ may donate embryos found to carry genetic markers without decreasing her chance of pregnancy or increasing her risk of harm. However, this type of genetic analysis is rarely performed in Canada and thus is not a sufficient source of embryos for hESC researchers here.

Physicians may be in a conflict of interest when approaching patients to donate fresh embryos because of subtle imperatives to aid hESC research. These imperatives may be collegial, academic, institutional, financial or altruistic (to help Canadians with conditions that may in future be ameliorated by hESC research). Potential academic and financial conflicts of interest in hESC research are recognized in the AHR Act ${ }^{7}$ and CIHR's stem cell research guidelines, ${ }^{6}$ which prohibit physicians who offer the choice of cryopreserved embryo donation from being part of an hESC research team or included as authors of related publications. Broader discussion is needed that would inform physicians not only how to "recognize and disclose" ${ }^{1}$ these and other conflicts of interest, but how to vacate them. For example, should physicians who stand to gain academically or financially from fresh embryo donation ask a colleague to approach their patients about the possibility of donation, rather than approach the patients themselves? Or should the patients of such physicians not be offered such a choice at all? Should it be only physicians with no academic or financial interest in fresh embryo donation who approach their own patients? Or should no patients be approached under any circumstances, since donation of their fresh embryos would decrease their chance of pregnancy and increase their risk of harm? The Assisted Human Reproduction Agency, charged with overseeing the AHR Act, ${ }^{7}$ will likely address such questions, but it has yet to be created.

Although probably legally permissible under Canada's AHR Act ${ }^{7}$ and CIHR's stem cell research guidelines, ${ }^{8}$ the practice of physicians offering their patients the choice to donate fresh embryos to stem cell research may be morally problematic under the CMA Code of Ethics. Many physicians may unknowingly become complicit in decreasing their patients' chance of pregnancy and increasing their risk of harm. We suggest an immediate moratorium on fresh- embryo donation until professional practice guidelines and other national regulations are developed that are consistent with the CMA Code of Ethics.

This article has been peer reviewed.

From the Departments of Obstetrics and Gynaecology and of Oncology, and the Medical Ethics and Humanities Program, Schulich School of Medicine and Dentistry (Nisker), the Department of Philosophy (White), University of Western Ontario, and the London Health Sciences Centre, University Campus (Nisker), London, Ont.

Competing interests: None declared.

Contributors: Both authors contributed equally to the concept and all stages of the research and writing of the manuscript and provided final approval of the version to be published.

Acknowledgement: We gratefully acknowledge Françoise Baylis, Mick Bhata and Natalie Ram for their insight during the early stages of this research and for their comments on preliminary drafts of the manuscript.

\section{References}

1. Canadian Medical Association. Code of ethics. Ottawa: The Association; 2004 Available: www.cma.ca/index.cfm/ci_id/2419/la_id/1.htm (accessed 2005 Aug 9).

2. Hwang, Ryu YJ, Park JH, Park ES, Lee EG, Koo JM, et al. Evidence of a pluripotent human embryonic stem cell line derived from a cloned blastocyst. Science 2004;303(5664):1669-74.

3. Hwang, Roh SI, Lee BC, Kang SK, Kwon DK, Kim S, et al. Patient-specific embryonic stem cells derived from human SCNT blastocysts. Science 2005 ; 308(5729):1777-83.

4. Rook K. Canadian stem-cell research wins approval. Globe and Mail [Toronto] 2005 June 9; Sect A:13.

5. Trounson A, Mohr L. Human pregnancy following cryopreservation, thawing and transfer of an eight-cell embryo. Nature 1983;305(5936):707-9.

6. American Society of Reproductive Medicine. Donating spare embryos for embryonic stem cell research. Birmingham (AL): The Society; 2002. Available: www.asrm.org/Media/Ethics/donatingspare.pdf (accessed 2005 Aug 9).

7. Assisted Human Reproduction Act (Attorney General). 2004 SCC 40(3.1).

8. Canadian Institutes for Health Research. Updated guidelines for buman pluripotent stem cell research, 7une 7, 2005. Ottawa: The Institutes; 2005. Available: www.cihr-irsc.gc.ca/e/28216.html (accessed 2005 Aug 18).

9. Human Fertilisation and Embryology Authority. Regulation of research on buman embryos. London (UK): The Authority; 2004. Available: www.hfea .gov.uk/Research/Policy/Licensing_the_use_of_Human_Embryos.pdf (accessed 2005 Aug 9).

10. Bush GW. Remarks by the President on stem cell research. 2001. Available: www.whitehouse.gov/news/releases/2001/08/print/20010809-2.html (accessed 2005 Aug 9).

11. Kenny NP. The ethics of care and the patient-physician relationship. Ann $R$ Coll Physicians Surg Can 1994;27(6):356-8.

12. Sherwin S. A relational approach to autonomy in health-care. In: Sherwin S, coordinator. The politics of women's health: exploring agency and autonomy. Philadelphia (PA): Temple University Press; 1998. p. 19-47.

13. Bubela TM, Caulfield TA. Do the print media "hype" genetic research? A comparison of newspaper stories and peer-reviewed research papers. CMAJ 2004;170(9):1399-407.

14. Nisker JA, Gore-Langton RE. Pre-implantation genetic diagnosis: a model of progress and concern. 7 Soc Obstet Gynaecol Can 1995;17(3):247-62.

Correspondence to: Dr. Jeffrey Nisker, London Health Sciences Centre, University Campus, Rm. 9E20, 339 Windermere Rd., London ON N6A 5A5; fax 519 663-3808; jeff.nisker@Ihsc.on.ca 